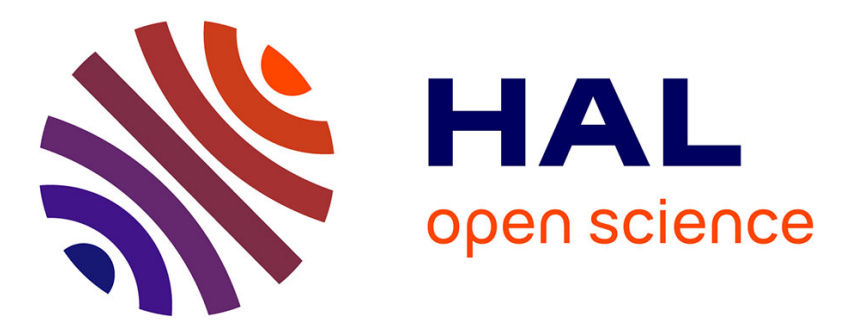

\title{
Selecting fish-based metrics responding to human pressures in French natural lakes and reservoirs: towards the development of a fish-based index (FBI) for French lakes
}

\author{
L. Launois, J. Veslot, P. Irz, C. Argillier
}

\section{- To cite this version:}

L. Launois, J. Veslot, P. Irz, C. Argillier. Selecting fish-based metrics responding to human pressures in French natural lakes and reservoirs: towards the development of a fish-based index (FBI) for French lakes. Ecology of Freshwater Fish, 2010, 20 (1), p. 120 - p. 132. 10.1111/j.1600-0633.2010.00467. hal-00856656

\section{HAL Id: hal-00856656 \\ https://hal.science/hal-00856656}

Submitted on 2 Sep 2013

HAL is a multi-disciplinary open access archive for the deposit and dissemination of scientific research documents, whether they are published or not. The documents may come from teaching and research institutions in France or abroad, or from public or private research centers.
L'archive ouverte pluridisciplinaire HAL, est destinée au dépôt et à la diffusion de documents scientifiques de niveau recherche, publiés ou non, émanant des établissements d'enseignement et de recherche français ou étrangers, des laboratoires publics ou privés. 
Launois, L., Veslot, J., Irz, P., and Argillier, C. (2010) Selecting fish-based metrics responding to human pressures in French natural lakes and reservoirs:towards the development of a fish-based index (FBI) for French lakes, Ecology of Freshwater Fish 2010.2010 John Wiley \& Sons A S. Accepted for publication October 12, 2010 - author-produced version of the final draft post-refeering

The original publication is available at $\mathrm{http}$ ___authorservices.wiley.com_bauthor_onlineLibraryTPS.asp_DOI=10.1111_j.1600-

0633.2010.00467.pdf

Selecting fish-based metrics responding to human pressures in French natural lakes and reservoirs: towards the development of a fish-based index (FBI) for French lakes.

Running headline: Response of fish-based metrics to human pressures in French lakes.

Lionel Launois ${ }^{1}$, Jacques Veslot, Pascal Irz and Christine Argillier

L. Launois, J. Veslot, P. Irz and C. Argillier. Cemagref. Unité de Recherche Hydrobiologie, Pôle Hydroécologie - Plans d'eau, 3275 route de Cézanne, CS 40061, 13182 Aix-en-Provence Cedex 5, France

ABSTRACT (Word count: 149 words)

1. Fish-based indices of biotic integrity (IBI) have been developed for many lotic systems but remain scarce for lakes. The goal of the present study was to assess the responses of lentic fish assemblages to anthropogenic pressures when environmental variability was controlled for, and to compare them between French natural lakes and reservoirs.

2. Environmental features, catchment-scale anthropogenic descriptors and fish data were collected from 30 natural lakes and 59 reservoirs throughout France.

3. Functional fish metrics were regressed against both anthropogenic variables and the natural environmental conditions.

Our results show that fish assemblages are appropriate ecological indicators for both natural and artificial lakes. They underline the necessity to control for the environment when

\footnotetext{
${ }^{1}$ Corresponding authors' present address: Cemagref. Unité de Recherche Hydrobiologie, Pôle Hydroécologie Plans d'eau, 3275 route de Cézanne, CS 40061, 13182 Aix-en-Provence Cedex 5, France.

E-mail address: lionel.launois@cemagref.fr.

Tel: $(+33) 442667938$.

Fax: (+33)4 42669934 .
} 
Launois, L., Veslot, J., Irz, P., and Argillier, C. (2010) Selecting fish-based metrics responding to human pressures in French natural lakes and reservoirs:towards the development of a fish-based index (FBI) for French lakes, Ecology of Freshwater Fish 2010.2010 John Wiley \& Sons A S. Accepted for publication October 12, 2010 - author-produced version of the final draft post-refeering

The original publication is available at http:__authorservices.wiley.com_bauthor_onlineLibraryTPS.asp_DOI=10.1111_j.1600-

0633.2010.00467.pdf

developing indices at broad geographical scales. The relevant metrics differ between natural lakes and for reservoirs, which challenges the attempts to use natural systems as references to assess the ecological potential of artificial ones.

Six keywords: functional metric $\bullet$ fish assemblage $\bullet$ natural lake and reservoir $\bullet$ index of biotic integrity • European Water Framework Directive• bioassessment

Number of references: 80 .

Word count: 4700 words. 
Launois, L., Veslot, J., Irz, P., and Argillier, C. (2010) Selecting fish-based metrics responding to human pressures in French natural lakes and reservoirs:towards the development of a fish-based index (FBI) for French lakes, Ecology of Freshwater Fish 2010.2010 John Wiley \& Sons A S. Accepted for publication October 12, 2010 - author-produced version of the final draft post-refeering

The original publication is available at http:__authorservices.wiley.com_bauthor_onlineLibraryTPS.asp_DOI=10.1111_j.1600-

0633.2010.00467.pdf

\section{Introduction}

Frey (1977) and then Karr and Dudley (1981) defined the concept of ecological integrity of freshwater ecosystems as their ability to support and maintain "a balanced, integrated, adaptive community of organisms having a species composition diversity and functional organization comparable to that of the natural habitat of the region." Since this publication, fish assemblages have become accepted as reflecting the "overall integrity of biological communities" and as "excellent indicators of the environmental quality of aquatic ecosystems" (Fausch et al. 1990).

Following Karr's studies on Midwestern U.S. streams, many other multimetric fish-based indices of biotic integrity (IBIs) have been developed for the running waters of North and Central America, and Europe (Hughes \& Oberdorff 1999; Miller et al. 1988; Roset et al. 2007; Simon \& Lyons 1995).

Conversely, the development of IBIs for lakes remains scarce (Appelberg et al. 2000; Drake \& Pereira 2002). The main difficulty hampering this development was heterogeneity in fish sampling (Jackson \& Harvey 1997). Even scarcer are the attempts to assess the quality of reservoirs using fish assemblages (but see Hickman and McDonough 1996; Jennings et al. 1995), despite their importance for water resource managers (Jennings et al. 1995). One reason put forward was that reservoirs are artificial systems that lack natural reference sites to assess the deviation from unaffected natural conditions (Hickman \& McDonough 1996; Jennings et al. 1995).

In Europe, the implementation of the European Water Framework Directive (WFD) (European Community 2000) requires the use of fish-based tools to assess the ecological status of all lentic water bodies, i.e., natural lakes and reservoirs, over 50 ha. The first multimetric index for lake fish was developed in Sweden (Appelberg et al. 2000; Holmgren et al. 2007). However, completed fish-based indices still remain rare and concern almost solely natural lakes. Moreover, they generally focus on specific types of environments (e.g., mountain or wetland lakes) and they are often based on taxonomic metrics, which are poorly transferable due to limited fish species distribution areas. In this context, the development of methods for monitoring the biological responses of fish assemblages to natural and anthropogenic factors is essential and remains to be improved. This is particularly true in some countries (e.g., France, Spain, Portugal, the Czech Republic) where most lakes are manmade. 
Launois, L., Veslot, J., Irz, P., and Argillier, C. (2010) Selecting fish-based metrics responding to human pressures in French natural lakes and reservoirs:towards the development of a fish-based index (FBI) for French lakes, Ecology of Freshwater Fish 2010.2010 John Wiley \& Sons A/S. Accepted for publication October 12, 2010 - author-produced version of the final draft post-refeering

The original publication is available at http:__authorservices.wiley.com_bauthor_onlineLibraryTPS.asp_DOI=10.1111_j.1600-

0633.2010.00467.pdf

Reservoirs are frequently considered as an intermediate between rivers and lakes (Gelwick \& Matthews 1990; Irz et al. 2006; Wetzel 1990): however, biological cross-ecosystem studies are currently not common (Pace 1991). Nevertheless, reservoirs satisfy some of the definition criteria of lakes (Politou et al. 1993), because most of the major processes (e.g., internal mixing, nutrient uptake, predator-prey interactions) occur in both natural lakes and reservoirs (Thornton 1990). Currently, the question of whether a common fish-based index could be used for both lentic ecosystems has been raised.

Therefore, the goals of this study were (i) to test if some candidate metrics, including functional metrics, are correlated to anthropogenic pressure gradients when the environment is controlled for in each type of lentic ecosystem and (ii) to compare the selected metrics between natural lakes and reservoirs.

\section{Study Sites}

Throughout this article we refer to lakes of natural origin as natural lakes and to manmade lentic systems as reservoirs; the generic term 'lakes' is used for both types. Only freshwater lakes are included in the present study.

Anthropogenic pressure indices were computed using 40 natural lakes and 106 reservoirs located throughout France. Fish data were collected from 30 natural lakes and 59 reservoirs among these 146 lakes (Figure 1). The lake data set represented a wide range of each environmental condition (Table 1), but as demonstrated in previous works on French lakes (Argillier et al. 2002b; Irz et al. 2004a; Irz et al. 2002), sites with altitudes over 1500 meters above sea level had to be excluded from these analyses because they shelter only introduced fish species. Scheduled locations of Figure 1 and Table 1.

\section{Material and methods}

Environmental parameters. - Five large-scale environmental parameters related to lake and drainage basin morphology, and known to affect the distribution patterns of fish assemblages, were considered (Table 1). The lake area $\left(A_{L}\right)$ is a strong predictor of fish richness (Barbour \& Brown 1974; Eadie \& Keast 1984); the drainage basin area $\left(A_{D B}\right)$ is an indicator of habitat diversity upstream of lake and of inflows into lakes (Irz et al. 2004b); the maximum depth $\left(D_{\max }\right)$ acts both directly on fish habitat availability by determining the importance of the lake littoral zone (Argillier et al. 2002c) and indirectly on the lake water dissolved oxygen level 
Launois, L., Veslot, J., Irz, P., and Argillier, C. (2010) Selecting fish-based metrics responding to human pressures in French natural lakes and reservoirs:towards the development of a fish-based index (FBI) for French lakes, Ecology of Freshwater Fish 2010.2010 John Wiley \& Sons A/S. Accepted for publication October 12, 2010 - author-produced version of the final draft post-refeering

The original publication is available at http:__authorservices.wiley.com_bauthor_onlineLibraryTPS.asp_DOI=10.1111_j.1600-

0633.2010.00467.pdf

(Hondzo \& Stefan 1996); the lake shoreline development factor (SLDF) (Eadie \& Keast 1984) accounts for an indicator of habitat diversity into lakes; and the volume development $\left(V_{d}\right)$ (Håkanson 1981) gives information on the lake basin shape and therefore on the size of the lake littoral zone. The AURELHY climate model (Benichou \& Le Breton 1987) was used to compute January and July mean air temperatures, because air temperatures are known to control the distribution of fish species (Daufresne \& Boet 2007; Irz et al. 2007b; Mason et al. 2008) by affecting the metabolism (Gillet 1991) and the growth of juveniles (Jensen 1990; Staggs \& Otis 1996) (SumT; DiffT; see Table 1). The hydrological model developed by Pella et al. (2006) was used to evaluate the lake yearly inflow in order to calculate residence time (RT). A geologic index (GI) displaying the percentage of the catchment area as calcareous, based on 1/50,000 geological maps (BRGM: http://www.brgm.fr/cartegeol.jsp), was computed on the whole lake catchment area. This GI enables us to understand lake catchment chemistry, which is an important factor affecting fish abundance (Shaw et al. 2004). Finally, the water level maximum amplitude (WL) was considered as an additional hydrological parameter, due to its detrimental effect on fish feeding conditions, sheltering and reproduction (Bragg et al. 2003; Winfield 2004).

Anthropogenic pressures. - Anthropogenic pressures were assessed for the overall French lake data set $(n=146)$ using seven variables derived from features of the lakes' catchments (Table 2). Land cover percentages allow evaluation of the agricultural and urban land use (Drake \& Pereira 2002). Population density relates to the watershed dynamic, especially chemical discharges into lakes (see Pitt et al. 1995). The network density of roads and railways reflects fragmentation (Forman \& Alexander 1998; Jones et al. 2000). The soil surface nitrogen balance and phosphorus balance were simulated using the NOPOLU System 2 model (PÖYRY) (LeGall, personal communication). These are the differences between the total quantity of nutrients entering the soil and the quantity leaving it annually. The nitrogen balance was kept as a pressure variable, but the phosphorus balance was adjusted according to the recommendation of Coale (2000). As particulate phosphorus is not very mobile (Carpenter et al. 1998), Coale proposed to multiply the phosphorus balance by the mean value of the lake's watershed soil erosion after $\log$ transformation $(\log (\mathrm{x}+1))$. This watershed soil erosion was estimated with a model developed by the French National Institute for Agricultural Research

(INRA

Ifen

Gis

Sol,

2000 
Launois, L., Veslot, J., Irz, P., and Argillier, C. (2010) Selecting fish-based metrics responding to human pressures in French natural lakes and reservoirs:towards the development of a fish-based index (FBI) for French lakes, Ecology of Freshwater Fish 2010.2010 John Wiley \& Sons A/S. Accepted for publication October 12, 2010 - author-produced version of the final draft post-refeering

The original publication is available at http:__authorservices.wiley.com_bauthor_onlineLibraryTPS.asp_DOI=10.1111_j.1600-

0633.2010.00467.pdf

http://eusoils.jrc.ec.europa.eu/ESDB Archive/serae/grimm/erosion/inra/europe/analysis/maps and listings/web erosion/index.html). This model is based on soil slumping, erodibility, topography, land cover, rainfalls and dominant cultivated land cover.

We assume that these seven variables derived from GIS data reflected the anthropogenic pressures undergone by lakes at the catchment scale. The population density and agricultural land cover were $\log$-transformed $(\log (\mathrm{x}+1))$ and the percentage of the urbanised catchment area was transformed to $\operatorname{arcsine} \sqrt{ }(X)$. The other four anthropogenic variables were kept raw.

In order to reduce dimensionality, a standardised principal component analysis (PCA) was performed on each group of anthropogenic variables (Table 2). On the one hand, we carried out a PCA on urban variables, and lake coordinates on the first principal component were considered a synthetic urban pressure variable (PU). The same was done on agricultural variables in order to create a synthetic agricultural pressure variable (PA). Scheduled location of Table 2.

Fish sampling procedures. - Fish data for the 89 French lakes were collected between 2005 and 2009 using a standardised method (C.E.N. 2005). A stratified random sampling scheme was implemented during summer (June-October, surface water temperature over $15^{\circ} \mathrm{C}$ ). The sampled lakes were divided into depth strata and randomly located samplings were performed within each depth stratum. Both pelagic and benthic multi-mesh gillnets made out of uncolored nylon were used. Benthic nets were $30 \mathrm{~m}$ long and $1.5 \mathrm{~m}$ deep and composed of 12 different mesh sizes (the panel for each mesh size was $2.5 \mathrm{~m}$ long) ranging between $5 \mathrm{~mm}$ to $55 \mathrm{~mm}$ following geometry series, with an approximately 1.25 ratio between mesh sizes. The pelagic nets were $27.5 \mathrm{~m}$ long and $6 \mathrm{~m}$ high and had the same mesh sizes without the $5 \mathrm{~mm}$ mesh size. The number of nets increased with lake depth and area. Nets were set around 7 p.m. for approximately $12 \mathrm{~h}$. Fish were identified to species and counted. The method provides the number of fish that were caught and the biomass for each one. We then calculated a whole-lake estimate for species relative abundances (RA), expressed as the ratio of the number of individuals belonging to a fish species to the total number of individuals in the lake; catch per unit effort (CPUE), and biomass (in grams) per unit effort (BPUE) (including both the benthic and the pelagic nets), respectively expressed as the overall number of individuals or biomass captured divided by the unit-of-effort (i.e., nets' surfaces multiplied 
Launois, L., Veslot, J., Irz, P., and Argillier, C. (2010) Selecting fish-based metrics responding to human pressures in French natural lakes and reservoirs:towards the development of a fish-based index (FBI) for French lakes, Ecology of Freshwater Fish 2010.2010 John Wiley \& Sons A/S. Accepted for publication October 12, 2010 - author-produced version of the final draft post-refeering

The original publication is available at http:__authorservices.wiley.com_bauthor_onlineLibraryTPS.asp_DOI=10.1111_j.1600-

0633.2010.00467.pdf

by the sampling duration). Finally, this method provided fish data that were comparable over time within a lake and between lakes.

Candidate metrics. - Altogether, 42 species were caught in these 89 lakes (Table 3). Scheduled location of Table 3.

Ten biological traits (Table 4) derived from functional guilds were used: two from tolerance guilds (overall tolerant (OTol) and overall intolerant (OIntol)), three from reproductive guilds (lithophilic species (Lith), strict lithophilic species (StLith), and strict phytophilic species (StPhyto)), and five from trophic guilds (omnivorous (Omni), invertivorous (Invert), planktivorous (Plankt), herbivorous (Herb) and piscivorous species (Pisc)). The 42 fish species caught were assigned to these attributes (Appendix 1), based on previous grey or published literature, online resources (Froese \& Pauly 2009 http://www.fishbase.org/; Pont et al. 2006) or expert judgments (H. Persat, O. Schlumberger $\&$ N. Poulet, personal communications). In addition, native species (Nat) were distinguished using Keith \& Allardi's (2001) classification. Scheduled location of Table 4.

A set of candidate metrics was derived from species richness and faunal composition as in other lake and stream IBIs (Drake \& Pereira 2002; Holmgren et al. 2007; Karr et al. 1986; Minns et al. 1994; Schulz et al. 1999). These metrics (Table 5) were expressed as (i) number of species sharing a trait ( $\mathrm{Sp}$ trait), (ii) number of species sharing a trait divided by the total number of species in the lake (\%Sp_trait), (iii) number of individuals sharing a trait caught by unit effort ( $\mathrm{Nb}$ trait), (iv) number of individuals sharing a trait divided by the total number of individuals in the lake (\%Nb_trait), (v) biomass of individuals sharing a trait caught by unit effort (B_trait) or (vi) biomass of individuals sharing a trait divided by the total biomass of individuals in the lake (\%B_trait). The total species richness (RS) metric was calculated, and three diversity indices based on fish abundances in each sampled site - i.e., Shannon's index (SWI) (Shannon \& Weaver 1949), Simpson's index (SI) (Simpson 1949) and evenness index (EI) (Hill 1973) - were also considered, as well as BPUE, CPUE and the average biomass (AB) calculated for each lake sampled as the ratio of BPUE to CPUE (Table 5). Scheduled

\section{location of Table 5.}

All functional fish traits considered here are shared by at least three species. Moreover, as in other studies (Irz et al. 2007a; Jennings et al. 1995; Pont et al. 2007), introduced species 
Launois, L., Veslot, J., Irz, P., and Argillier, C. (2010) Selecting fish-based metrics responding to human pressures in French natural lakes and reservoirs:towards the development of a fish-based index (FBI) for French lakes, Ecology of Freshwater Fish 2010.2010 John Wiley \& Sons A/S. Accepted for publication October 12, 2010 - author-produced version of the final draft post-refeering

The original publication is available at http:__authorservices.wiley.com_bauthor_onlineLibraryTPS.asp_DOI=10.1111_j.1600-

0633.2010.00467.pdf

were not excluded from the metrics calculations because they may play an important functional role in lake ecosystems.

This set of metrics reflects complementary aspects of assemblage richness and functioning.

Statistical analysis. - For environmental variables, to retrieve less skewed distributions, the residence time, catchment area, lake area and maximum depth were log-transformed. For biological variables, classic monotonic transformations were used to meet the requirements of the linear model (normality, linearity, homoscedasticity): count (abundance, richness) and biomass metrics were log-transformed, proportion metrics were arcsine-square-roottransformed, whereas diversity indices were kept untransformed. These metrics were then scaled and the variation partitioning of each metric was performed using constrained redundancy analysis (Legendre \& Legendre 1998). Here, with a single response variable, redundancy analysis consists in a multiple linear regression on the principal components of predictors with orthogonal residuals. The three sets of predictors involved are: the ten environmental predictors, the agricultural pressure index (PA) and the urban pressure index (PU). A permutation test based on residuals after partial RDA was used to assess the significance of the parts of variance explained solely by PA and solely by PU.

Each metric significantly explained by at least one of the two pressure indices was then regressed using a stepwise "both sides" selection of predictors based on Bayesian information criterion (BIC) from the complete model:

$$
\text { Metric } \sim\left(\mathrm{A}_{\mathrm{L}}+\mathrm{A}_{\mathrm{DB}}+\mathrm{D}_{\max }+\mathrm{SLDF}+\mathrm{V}_{\mathrm{d}}+\mathrm{SumT}+\mathrm{DiffT}+\mathrm{RT}+\mathrm{GI}+\mathrm{WL}\right)+\mathrm{PA}+\mathrm{PU}(1)
$$

The pressure effect of a given pressure on a metric was considered only if: (i) the adjusted R-squared of the resulting model was higher than 0.2 ; (ii) the coefficient of that pressure in the resulting model was significantly different from zero; and (iii) the pressure was also included in the best model selected on the basis of the root mean square error (RMSE) using a leave-one-out cross-validation procedure (LOO).

All statistical analyses were performed using R statistical software (R.2.9.1) as well as 'vegan', 'pls', and 'caret' R packages (Ihaka \& Gentleman 1996; R Development Core Team 2008). 
Launois, L., Veslot, J., Irz, P., and Argillier, C. (2010) Selecting fish-based metrics responding to human pressures in French natural lakes and reservoirs:towards the development of a fish-based index (FBI) for French lakes, Ecology of Freshwater Fish 2010.2010 John Wiley \& Sons A S. Accepted for publication October 12, 2010 - author-produced version of the final draft post-refeering

The original publication is available at http:__authorservices.wiley.com_bauthor_onlineLibraryTPS.asp_DOI=10.1111_j.1600-

0633.2010.00467.pdf

\section{Results}

Study sites and environmental parameters. - In the present study, natural lakes are located either in mountain areas (e.g., the Alps, the Massif Central) or next to the coast (Figure 1). On the contrary, reservoirs are roughly randomly spread throughout France. The mean values of most environmental parameters are quite similar between natural lakes and reservoirs, although natural lakes have larger residence time (692 days vs. 137 days) (Student $t$-test with Welch correction, $\mathrm{t}=2.16, P<0.05$ ) (Table 1), lower SLDF (with Welch correction, $\mathrm{t}=-$ 6.83, $P<0.001)$, smaller catchment areas $(\mathrm{t}=-3.29, P<0.001)$ and lower water level fluctuations $(\mathrm{t}=-7.53, P<0.001)$ than reservoirs.

Differences between lake types are clearer with respect to anthropogenic pressures (Table 2). Apart from network densities and urbanised areas, all anthropogenic pressures displayed higher mean values for artificial lakes than for natural ones. For natural lakes, the negative nutrient balances indicate a deficit of nutrients in the soil surface of the catchment, whereas their highly positive values for reservoirs show a nutrient accumulation. In addition, all agricultural variables reached higher maximum values for reservoirs than for natural lakes more than twice as much. For example, reservoirs have higher maximum values of agriculture land cover areas $\left(8,783.4 \mathrm{~km}^{2}\right.$ vs. $\left.790.6 \mathrm{~km}^{2}\right)$ and nutrient balances $(877.1 \mathrm{t}(\mathrm{N})$ vs. $432.3 \mathrm{t}(\mathrm{N})$, and $2,523.1 \mathrm{t}(\mathrm{P})$ vs. $849.2 \mathrm{t}(\mathrm{P}))$ than natural lakes. In summary, reservoirs undergo much more agricultural pressure than natural lakes do.

Fish sampling and candidate metrics. - Lakes and reservoirs are very similar in terms of common and rare species (Table 3). Indeed, $68 \%$ of the fish species occur in both types of ecosystems. In both natural lakes and reservoirs, Perca fluviatilis (Linnaeus, 1758), Rutilus, rutilus (L., 1758) and Scardinius erythrophthalmus (L., 1758) were widespread (more than two-thirds of the sampling sites) and had a high mean relative abundance ( $>5 \%$ in at least one of two types). In addition, fish species with low occupancy ( $<10 \%$ of the sampling sites) and poor average relative abundance $(<1 \%$ in at least one of the system types) were nearly the same as well (Table 3). On the contrary we observed clear differences ( $\geq 25 \%$ in frequency) between lake types concerning Abramis brama (L., 1758), Alburnus alburnus (L., 1758), Blicca bjoerkna (L., 1758), Gymnocephalus cernuus (L., 1758), Sander lucioperca (L., 1758) and Coregonus lavaretus (L., 1758) (Table 3). All of them, except the last one were more frequent in reservoirs than in natural lakes. 
Launois, L., Veslot, J., Irz, P., and Argillier, C. (2010) Selecting fish-based metrics responding to human pressures in French natural lakes and reservoirs:towards the development of a fish-based index (FBI) for French lakes, Ecology of Freshwater Fish 2010.2010 John Wiley \& Sons A S. Accepted for publication October 12, 2010 - author-produced version of the final draft post-refeering

The original publication is available at http:__authorservices.wiley.com_bauthor_onlineLibraryTPS.asp_DOI=10.1111_j.1600-

0633.2010.00467.pdf

Most of the functional fish-based metrics also indicated similarities between lake types (Student $t$-test, with Welch correction if needed, see Table 5).

Overall, 11 out of 73 candidate fish metrics displayed a significant response to anthropogenic pressures (Table 6). None of the metrics based on the lithophilic, strict lithophilic, intolerance, and invertivorous traits displayed a significant response. Moreover, anthropogenic impacts do not appear significant on species richness or on diversity indices. In addition, none of the candidate metrics indicated a significant anthropogenic impact on both natural lakes and reservoirs. Scheduled location of Table 6.

Three metrics displayed a significant response to anthropogenic pressures in natural lakes (Table 6). \%B_OTol increases with urbanisation stress (30\% of the variance explained). $\mathrm{Nb}$ _StPhyto and \%B_Plankt seem to be good indicators of agricultural impacts (Table 6) ( $20 \%$ and $17 \%$ of variance, respectively, explained exclusively by agricultural pressure).

For the reservoirs, eight metrics were selected, including BPUE (Table 6). Five of them relate to assemblage trophic structure and two to tolerance guild metrics (Sp_OTol and B_OTol). The only type of pressure significantly contributing to the model was PA (Table 6). Apart from the percentage of piscivorous species, the other seven metrics displayed a positive response to the agricultural pressure when the environment was controlled for. The metric $\% \mathrm{Sp} \_$Pisc showed the strongest response with $17 \%$ of its variance attributed to PA. B_Herb and \%Sp_Plankt came next with $13 \%$ and $12 \%$, respectively.

All linear models included at least one significant coefficient for environmental variables (unpublished results). This highlights the importance of accounting for the environmental patterns of variability when studying the response of fish-based metrics to anthropogenic pressures at broad spatial scales. For the natural lakes, this is particularly true for the $\%$ B_Plankt and \%B_OTol (Table 6), with 28\%, and 27\%, respectively, of their variance attributed to environmental variables. For reservoirs, this mostly concerns B_OTol and BPUE, with $38 \%$, and $37 \%$, respectively, of their variance explained by environmental variables.

\section{Discussion}

The data set processed here can be considered representative of the diversity of lakes at the national scale (excluding lakes above $1500 \mathrm{~m}$ ). Although natural lakes and reservoirs both meet the generic definition of lakes (Politou et al. 1993), they clearly differ in terms of 
Launois, L., Veslot, J., Irz, P., and Argillier, C. (2010) Selecting fish-based metrics responding to human pressures in French natural lakes and reservoirs:towards the development of a fish-based index (FBI) for French lakes, Ecology of Freshwater Fish 2010.2010 John Wiley \& Sons A/S. Accepted for publication October 12, 2010 - author-produced version of the final draft post-refeering

The original publication is available at http:__authorservices.wiley.com_bauthor_onlineLibraryTPS.asp_DOI=10.1111_j.1600-

0633.2010.00467.pdf

morphological characteristics, functioning (e.g., water level fluctuation (Table 1)) and anthropogenic pressures (Cooke et al. 1993; Thornton 1990). Reservoirs undergo much more agricultural pressures than natural lakes do certainly because the storage of water in artificial lakes favors the development of irrigation.

\section{Assessing lake conditions through fish assemblages}

The present study provides evidence that fish assemblages are good potential indicators of urban and agricultural impacts on lakes. Eleven metrics (among the initial set of 73) responded to the lake catchment pressures when the environment was controlled for.

Most of the selected metrics responded to agricultural pressures. This prevailing effect of agriculture versus urban land use can be explained by the differences in intensity of these two pressures. The mean percentage of agricultural land cover in catchments exceeds by one order of magnitude that of urban land use (Table 2). The buiding of treatment plants for domestic and industrial sewage certainly contributed to mitigate the impact of urban land use on freshwater ecosystems. Conversely, agriculture is still a major user of fertilisers and pesticides, and it contributes to soil erosion. In this context the prominent effect of agriculture on freshwater assemblages is not really surprising, even though the processes involved remain unclear. Direct impacts (e.g., by toxicity) are certainly less important than those explained by habitat alteration or eutrophication. Finally, there is also more variability in agricultural than in urban land cover (synthesized by higher SD, see Table 2), which may explain a clearer response of fish-based metrics. Moreover, in the present study, the urbanisation of catchments was very low compared to that in other studies (Drake \& Pereira 2002; Whittier 1999). In addition, the lack of significance might also be due to the fact that these relationships between metrics and pressures are actually non-linear, which was not considered here. Metrics might indeed be, for example, sensitive to a given pressure above a certain threshold.

Regarding natural lakes only three metrics displayed a significant response to anthropogenic pressures (Table 6). This is less than for reservoirs, which may be explained by the above-mentioned differences in the agricultural pressure between natural lakes and reservoirs. Furthermore, we have to acknowledge that the number of natural lakes included in the present study and the variability between these lakes (i.e. coastal to mountain lakes) may limit the possibility of identifying certain relevant metrics. Nevertheless, considering the low number (less than 70) of French natural lakes over 50 ha, this exercise will remain difficult at 
Launois, L., Veslot, J., Irz, P., and Argillier, C. (2010) Selecting fish-based metrics responding to human pressures in French natural lakes and reservoirs:towards the development of a fish-based index (FBI) for French lakes, Ecology of Freshwater Fish 2010.2010 John Wiley \& Sons A/S. Accepted for publication October 12, 2010 - author-produced version of the final draft post-refeering

The original publication is available at http:__authorservices.wiley.com_bauthor_onlineLibraryTPS.asp_DOI=10.1111_j.1600-

0633.2010.00467.pdf

a national scale, whatever the sampling method used. At the European level, similar tests would be more powerful.

Finally, it is obvious that fish management practices can influence fish species composition and abundance (Argillier et al. 2002a). However, in this study, fish species were considered self-sustaining. Indeed, all species are not stocked and when they are, according to our knowledge of local management practices, this is infrequent. Furthermore, even if none of the lakes studied was concerned with commercial fishing, we cannot exclude bias in our metric calculations (i.e., metrics related to the abundance of piscivores and salmonids) due to intensive recreational angling.

\section{Fish-based metric responses on both lentic ecosystems}

For planktivorous species, for example, agriculture has a significant effect on \%B_Plankt for natural lakes and on $\% \mathrm{Sp}$ _Plankt for reservoirs (Table 6), but no metric revealed a common response to a pressure on both natural lakes and reservoirs.

\section{The selected fish-based metrics}

Only fish-related metrics based on tolerance, reproduction, and trophic guilds were retained in this study. The tolerance-related metrics seemed to display clear responses to anthropogenic pressures both on reservoirs and natural lakes. Most IBIs developed on rivers (Oberdorff et al. 2002; Pont et al. 2006), reservoirs (Karr \& Dionne 1991; McDonough \& Hickman 1999) or natural lakes (Belpaire et al. 2000; Drake \& Pereira 2002) use some measure of the relative dominance of tolerant species to assess moderate to high levels of degradation (Simon \& Lyons 1995). Nevertheless, as discussed previously, the metric units of the selected tolerance-related metrics were different between natural lakes and reservoirs. Moreover, it is apparent that 5 of 11 intolerant species are salmonids (see Appendix 1) and they likely occupy mainly the coldwater lakes located above $1500 \mathrm{~m}$ that were excluded from our analyses. In spite of the absence of response of intolerant species-based metrics, most of our results confirm the value of tolerant-related metrics.

Apart from the proportion of piscivorous species, all other trophic-based metrics displayed significantly positive relationships with agricultural pressure, among both types of lakes. All six trophic-based metrics selected in this study responded similarly to those found in other IBI adaptation studies (Appelberg et al. 2000; Drake \& Pereira 2002; Jennings et al. 1995; Karr \& 
Launois, L., Veslot, J., Irz, P., and Argillier, C. (2010) Selecting fish-based metrics responding to human pressures in French natural lakes and reservoirs:towards the development of a fish-based index (FBI) for French lakes, Ecology of Freshwater Fish 2010.2010 John Wiley \& Sons A S. Accepted for publication October 12, 2010 - author-produced version of the final draft post-refeering

The original publication is available at http:__authorservices.wiley.com_bauthor_onlineLibraryTPS.asp_DOI=10.1111_j.1600-

0633.2010.00467.pdf

Dionne 1991). In contrast to temperate stream ecosystems, it is acknowledged that lentic ecosystems are considered more stable from an environmental point of view, thereby promoting intra-assemblage interactions (e.g., competition, predation) and giving rise to trophically structured assemblages (Hugueny \& Paugy 1995; Ibañez et al. 2009; Oberdorff et al. 1998). Hence, studying the response of the trophic composition metrics to anthropogenic pressures in lentic ecosystems was useful, while nutrient loadings induced by agricultural land use could probably modify the equilibrium between the different trophic levels (Carpenter et al. 1985; Vitousek et al. 1997).

Among the metric based on reproductive guilds, Nb_StPhyto was the only one that showed a significant response to agricultural pressure; this was observed only for natural lakes (Table 6).

\section{Candidate metrics displaying no response}

Species richness was not correlated to catchment-scale anthropogenic pressures. This is congruent with previous results (Irz et al. 2007a). Various responses were reported for this metric. It can increase due to eutrophication (Dodson et al. 2000; Mittelbach et al. 2001) or species introduction (Irz et al. 2004a), but decrease due to the extirpation of habitat-sensitive taxa (Corbacho \& Sanchez 2001).

The three diversity indices were not either correlated to anthropogenic factors. These indices have rarely been used in fish index development, probably because they are highly correlated with each other and because the information they provide is difficult to interpret (Holmgren et al. 2007). In addition, zoogeographic factors (e.g., post-glacial dispersal, hydrographic regions, and $\mathrm{pH}$ ) relevant for explaining species richness and diversity indices have not been considered in this analysis (Griffiths 1997; Irz et al. 2004a).

Despite a strong negative relationship between the native related metrics and anthropogenic pressures observed in other studies (e.g., Jennings et al. 1999), this association was not detected. However, the species driving this relation in the French data set were in the majority Rutilus rutilus (L., 1758), Perca fluviatilis (L., 1758), Blicca bjoerkna (L., 1758) and Abramis brama (L., 1758). These species are overall tolerant as regards degraded lake conditions. Hence, the selection of a fish species able to respond, depending on the biological trait that is studied, in both directions to degraded lake conditions explains why the response of those candidate metrics could be concealed in our study. The same explanation can be 
Launois, L., Veslot, J., Irz, P., and Argillier, C. (2010) Selecting fish-based metrics responding to human pressures in French natural lakes and reservoirs:towards the development of a fish-based index (FBI) for French lakes, Ecology of Freshwater Fish 2010.2010 John Wiley \& Sons A S. Accepted for publication October 12, 2010 - author-produced version of the final draft post-refeering

The original publication is available at http:__authorservices.wiley.com_bauthor_onlineLibraryTPS.asp_DOI=10.1111_j.1600-

0633.2010.00467.pdf

advanced to account for the absence of relationships between agricultural or urban pressure and fish-based metrics related to lithophilic, strict lithophilic, and invertivorous species.

In addition, the near absence of reproduction-related metric responses highlighted by this study may be the result of the poor relevance or the deficiency of the lake descriptors considered. It is commonly accepted that both local and large-scale processes influence local fish assemblages in lakes (Irz et al. 2007; Petesse et al. 2007). In this study, only large-scale pressures were considered and more relevant descriptors of habitat and hydromorphological alteration have to be collected; further studies will then be required to better understand the influence of regional versus local anthropogenic pressures on fish assemblages (Irz et al. 2007a).

Finally, the relationship between intolerant species-related metrics and anthropogenic pressures can be concealed, as reported by Irz et al. (2007a), because "a species could be considered as intolerant in some regions where it is restricted to some particular type of environment, and tolerant in another region where it is widespread." However, in this study we can note that, apart from Gobio gobio (L., 1758), all other fish species driving that relation had either low occupancy ( $<3 \%$ of the sampling sites) or poor average relative abundance $(<1 \%$ in at least one of both types). Consequently, intolerant species-related metrics displayed a very narrow range of variance, thus explaining their lack of response to anthropogenic pressures.

Additional work is needed, and as suggested by Berrebi-dit-Thomas et al. (1998) and Whittier et al. (2007), metrics based on biological traits that are the expression of specialized attributes (e.g., invertivores, lithophilic) should be calculated without considering overall tolerant fish species. Indeed, this modification may prevent the sensitivity of a specific biological parameter from being concealed due to the heterogeneity of the fish species contributing to the calculation of the fish-based metric.

\section{Multiple testing}

No corrections were made for multiple testing. We are aware of the increasing risk of false positive. However, there is much true dependence between the metrics tested since they are based on guild composed by partly the same species and for a given guild six metrics are based on the same species but measured differently. In short, because of this dependence, the 
Launois, L., Veslot, J., Irz, P., and Argillier, C. (2010) Selecting fish-based metrics responding to human pressures in French natural lakes and reservoirs:towards the development of a fish-based index (FBI) for French lakes, Ecology of Freshwater Fish 2010.2010 John Wiley \& Sons A S. Accepted for publication October 12, 2010 - author-produced version of the final draft post-refeering

The original publication is available at http:__authorservices.wiley.com_bauthor_onlineLibraryTPS.asp_DOI=10.1111_j.1600-

0633.2010.00467.pdf

true number of effective testing must be largely fewer than the number of metrics considered (Cheverud 2001). Nevertheless, much attention must be paid to the levels of significance.

\section{Conclusion}

The present study indicates that fish assemblages are appropriate ecological indicators for both natural and artificial lakes. Our results underline the necessity to control for the environment when developing FBIs at broad geographical scales. They also prove that the relevant metrics differ between natural lakes and for reservoirs. This challenges the attempts to use natural systems as references to assess the ecological potential of artificial ones.

\section{Acknowledgements}

The authors thank H. Persat (CNRS), N. Poulet (ONEMA), O. Schlumberger (Ministère de 1'Agriculture et de la Pêche), and C. Lanoiselée (CEMAGREF), who evaluated fish functional attributes. Our thanks are extended to G. Legall (PÖYRY Environmnent); V. Antoni (INRA Orléans); BRGM Orléans; INERIS; S. Alleaume, H. Pella and J.-M. Helmer (CEMAGREF); O. Coulon, L. Navarro and L. Fournier (Agences de 1'Eau); and V. Verneaux (Université de Franche-Comté) for assistance with data collection and with GIS land use data. Special thanks are also due to A. Brind'Amour and D. Pont, who both provided useful comments and ideas on this study. Funding from the Office National de 1'Eau et des Milieux Aquatiques (ONEMA) is appreciated. Finally, we thank four anonymous referees for reviewing this paper and providing helpful advice. 
Launois, L., Veslot, J., Irz, P., and Argillier, C. (2010) Selecting fish-based metrics responding to human pressures in French natural lakes and reservoirs:towards the development of a fish-based index (FBI) for French lakes, Ecology of Freshwater Fish 2010.2010 John Wiley \& Sons A S. Accepted for publication October 12, 2010 - author-produced version of the final draft post-refeering

The original publication is available at http:__authorservices.wiley.com_bauthor_onlineLibraryTPS.asp_DOI=10.1111_j.1600-

0633.2010.00467.pdf

\section{References}

Appelberg, M., Bergquist, B.C. \& Degerman, E. 2000. Using fish to assess environmental disturbance of Swedish lakes and streams - a preliminary approach. Verhandlungen der Internationalen Vereinigung fuer Limnologie 27: 311-315.

Argillier, C., Pronier, O. \& Changeux, T. 2002a. Fishery management practices in French lakes. In: Cowx, I.G., ed. Management and ecology of lake and reservoir fisheries. Fishing News Books. Oxford: Blackwell Science, pp. 312-321.

Argillier, C., Pronier, O. \& Irz, P. 2002b. Approche typologique des peuplements piscicoles lacustres Français. I. Les communautés des plans d'eau d'altitude supérieure à $1500 \mathrm{~m}$. Bulletin Français de Pêche et de Pisciculture 365/366: 373-387.

Argillier, C., Pronier, O., Irz, P. \& Molinier, O. 2002c. Approche typologique des peuplements piscicoles lacustres Français. II. Structuration des communautés dans les plans d'eau d'altitude inférieure à $1500 \mathrm{~m}$. Bulletin Français de Pêche et de Pisciculture 365/366: 389-404.

Barbour, C.D. \& Brown, J.H. 1974. Fish species diversity in lakes. American Naturalist 108: 473-489.

Benichou, P. \& Le Breton, O. 1987. Prise en compte de la topographie pour la cartographie des champs pluviométriques statistiques. La Météorologie 7: 23-34.

Berrebi dit Thomas, R., Belliard, J. \& Boët, P. 1998. Caractéristiques des peuplements piscicoles sensibles aux altérations du milieu dans les cours d'eau du bassin de la Seine. Bulletin Français de Pêche et de Pisciculture 348: 47-64.

Bragg, O.M., Duck, R.W., Rowan, J.S. \& Black, A.R. 2003. Review of methods for assessing the hydromorphology of lakes. Environment Agency, University of Dundee, $130 \mathrm{pp}$.

C.E.N. 2005. Water Quality - Sampling of fish with multi-mesh gillnets. 26 pp.

Carpenter, S.R., Caraco, N.F., Correll, D.L., Howarth, R.W., Sharpley, A.N. \& Smith, V.H. 1998. Nonpoint pollution of surface waters with phosphorus and nitrogen. Ecological Applications 8: 559-568.

Carpenter, S.R., Kitchell, J.F. \& Hodgson, J.R. 1985. Cascading trophic interactions and lake productivity. Bioscience: 634-639.

Cheverud, J. 2001. A simple correction for multiple comparisons in interval mapping genome scans. Heredity 87: 52-58.

Coale, F.J. 2000. The Maryland Phosphorus Site Index (PSI) technical user's guide. Soil Fertility Management Information Series, SFM-7. Maryland Extension Service. College Park, MD, 20742: University of Maryland, Department of Natural Resource Sciences and Landscape Architecture.

Cooke, G.D., Welch, E.B., Peterson, S.A. \& Newroth, P.R. 1993. Restoration and management of lakes and reservoirs (2nd edn). Boca Raton, FL: Lewis Press. 548 pp. pp.

Corbacho, C. \& Sanchez, J.M. 2001. Patterns of species richness and introduced species in native freshwater fish faunas of a mediterranean-type basin: The Guadiana River (southwest Iberian Peninsula). Regulated Rivers: Research \& Management 17: 699-707.

Daufresne, M. \& Boet, P. 2007. Climate change impacts on structure and diversity of fish communities in rivers. Global Change Biology 13: 2467-2478.

Dodson, S.I., Arnott, S.E. \& Cottingham, K.L. 2000. The relationship in lake communities between primary productivity and species richness. Ecology 81: 2662-2679.

Drake, M.T. \& Pereira, D.L. 2002. Development of a fish-based index of biotic integrity for small inland lakes in central Minnesota. North American Journal of Fisheries Management 22: $1105-1123$. 
Launois, L., Veslot, J., Irz, P., and Argillier, C. (2010) Selecting fish-based metrics responding to human pressures in French natural lakes and reservoirs:towards the development of a fish-based index (FBI) for French lakes, Ecology of Freshwater Fish 2010.2010 John Wiley \& Sons A/S. Accepted for publication October 12, 2010 - author-produced version of the final draft post-refeering

The original publication is available at http:__authorservices.wiley.com_bauthor_onlineLibraryTPS.asp_DOI=10.1111_j.1600-

0633.2010.00467.pdf

Eadie, J.M. \& Keast, A. 1984. Resource heterogeneity and fish species diversity in lakes. Canadian Journal of Zoology 62: 1689-1695.

European Community. 2000. Directive 2000/60/EC of the European Parliament and of the Council. Official Journal.

Fausch, K.D., Lyons, J., Karr, J.R. \& Angermeier, P.L. 1990. Fish communities as indicators of environmental degradation. American Fisheries Society Symposium 8: 123-144.

Forman, R.T.T. \& Alexander, L.E. 1998. Roads and their major ecological effects. Annual Review of Ecology and Systematics 29: 207-231.

Frey, D.G. 1977. Biological integrity of water-an historical approach. In: Ballentine, R.K. \& Guarraia, L.J., eds. The integrity of water. Washington, D.C.: US Environmental Protection Agency, pp. 127-140.

Froese, R. \& Pauly, D. 2009. FishBase. In: World Wide Web electronic publication, ed.

Gelwick, F.P. \& Matthews, W.J. 1990. Temporal and spatial patterns in littoral-zone fish assemblages of a reservoir (lake Texoma, Oklahoma-Texas, USA). Environmental Biology of Fishes 27: 107-120.

Gillet, C. 1991. Egg production in an arctic charr (Salvelinus alpinus L.) brood stock: Effects of temperature on the timing of spawning and the quality of eggs. Aquatic Living Resources 4: 109-116.

Håkanson, L. 1981. A manual of lake morphometry. Berlin, Heidelberg, New York: SpringerVerlag.

Hill, M. 1973. Diversity and evenness: a unifying notation and its consequences. Ecology 54: 427-432.

Holmgren, K., Kinnerbäck, A., Pakkasmaa, S., Bergquist, B. \& Beier, U. 2007. Bedömningsgrunder för fiskfaunans status i sjöar. Fiskeriverket Informerar 3: 54.

Hondzo, M. \& Stefan, G. 1996. Long-term lake water quality predictors. Water Resources 30: 2835-2852.

Hughes, R.M. \& Oberdorff, T. 1999. Applications of IBI concepts and metrics to waters outside the United states and Canada. In: Simon, T.P., ed. Assessing the sustainability and biological integrity of water resource quality using fish communities. Boca Raton, Florida: CRC Press, pp. 79-93.

Hugueny, B. \& Paugy, D. 1995. Unsaturated fish communities in African rivers. American Naturalist 146: 162-169.

Ibañez, C., Belliard, J., Hughes, R.M., Irz, P., Kamdem-Toham, A., Lamouroux, N., Tedesco, P.A. \& Oberdorff, T. 2009. Convergence of temperate and tropical stream fish assemblages. Ecography 32: 658-670.

Ihaka, R. \& Gentleman, R. 1996. R: a language for data analysis and graphics. Journal of Computational and Graphical Statistics 5: 299-314.

Irz, P., Argillier, C. \& Oberdorff, T. 2004a. Native and introduced fish species richness in French lakes: local and regional influences. Global Ecology and Biogeography 13: 335-344.

Irz, P., Argillier, C. \& Proteau, J.-P. 2004b. Contribution of native and non-native species to fish communities in French reservoirs. Fisheries Management and Ecology 11: 165-172.

Irz, P., De Bortoli, J., Michonneau, F., Whittier, T.R., Oberdorff, T. \& Argillier, C. 2007a. Controlling for natural variability in assessing the response of fish metrics to human pressures for lakes in north-east USA. Aquatic Conservation: Marine and Freshwater Ecosystems 18: 633-646.

Irz, P., Laurent, A., Messad, S., Pronier, O. \& Argillier, C. 2002. Influence of site characteristics on fish community patterns in French reservoirs. Ecology Of Freshwater Fish 11: $123-136$. 
Launois, L., Veslot, J., Irz, P., and Argillier, C. (2010) Selecting fish-based metrics responding to human pressures in French natural lakes and reservoirs:towards the development of a fish-based index (FBI) for French lakes, Ecology of Freshwater Fish 2010.2010 John Wiley \& Sons A S. Accepted for publication October 12, 2010 - author-produced version of the final draft post-refeering

The original publication is available at http:__authorservices.wiley.com_bauthor_onlineLibraryTPS.asp_DOI=10.1111_j.1600-

0633.2010.00467.pdf

Irz, P., Michonneau, F., Oberdorff, T., Whittier, T.R., Lamouroux, N., Mouillot, D. \& Argillier, C. 2007b. Fish community comparisons along environmental gradients in lakes of France and Northeast U.S.A. Global Ecology and Biogeography 16: 350-366.

Irz, P., Odion, M., Argillier, C. \& Pont, D. 2006. Comparison between the fish communities of lakes, reservoirs and rivers: can natural systems help define the ecological potential of reservoirs? Aquatic Sciences 68: 109-116.

Jackson, D.A. \& Harvey, H.H. 1997. Qualitative and quantitative sampling of lake fish communities. Canadian Journal of Fisheries and Aquatic Sciences 54: 2807-2813.

Jennings, M.J., Fore, L.S. \& Karr, J.R. 1995. Biological monitoring of fish assemblages in Tennessee Valley reservoirs. Regulated Rivers: Research \& Management 11: 263-274.

Jennings, M.J., Lyons, J., Emmons, E.E., Hatzenbeler, G.R., Bozek, M.A., Simonson, T.D., Beard, T.D., Jr \& Fago, D. 1999. Toward the development of an index of biotic integrity for inland lakes in Wisconsin. In: Simon, T.P., ed. Assessing the sustainability and biological integrity of water resource quality using fish communities. Boca Raton, Florida: CRC Press, pp. 541-562.

Jones, J.A., Swanson, F.J., Wemple, B.C. \& Snyder, K.U. 2000. Effects of roads on hydrology, geomorphology, and disturbance patches in stream networks. Conservation Biology 14: 76-85.

Karr, J.R. \& Dionne, M. 1991. Designing surveys to assess biological integrity in lakes and reservoirs. Proceedings of the Proceedings of symposium - Biological criteria: research and regulation: $62-72$.

Karr, J.R. \& Dudley, D.R. 1981. Ecological perspective on water quality goals. Environmental Management 5: 55-68.

Keith, P. \& Allardi, J. 2001. Atlas des poissons d'eau douce de France. Patrimoines Naturels. Paris: Muséum National d'Histoire Naturelle, p. 387.

Legendre, P. \& Legendre, L. 1998. Numerical ecology. Amsterdam: Elsevier Science. 853 pp. Mason, N.W.H., Irz, P., Lanoiselée, C., Mouillot, D. \& Argillier, C. 2008. Evidence that niche specialization explains species-energy relationships in lake fish communities. Journal of Animal Ecology 77: 285-296.

McDonough, T.A. \& Hickman, G.D. 1999. Reservoir Fishery Assessment Index development: a tool for assessing ecological health in Tennessee Valley Authority impoundments. In: Simon, T.P., ed. Assessing the sustainability and biological integrity of water resource quality using fish communities. Boca Raton, Florida: CRC Press, pp. 523-540.

Miller, D.L., Hughes, R.M., Karr, J.R., Leonard, P.M., Moyle, P.B., Schrader, L.H., Thompson, B.A., Daniels, R.A., Fausch, K.D., Fitzhugh, G.A., Gammon, J.R., Halliwell, D.B., Angermeier, P.L. \& Orth, D.J. 1988. Regional Applications of an Index of Biotic Integrity for Use in Water Resource Management. Fisheries 13: 12-20.

Mittelbach, G.G., Steiner, C.F., Scheiner, S.M., Gross, K.L., Reynolds, H.L., Waide, R.B., Willig, M.R., Dodson, S.I. \& Gough, L. 2001. What is the observed relationship between species richness and productivity? Ecology 82: 2381-2396.

Oberdorff, T., Hugueny, B., Compin, A. \& Belkessam, D. 1998. Non-interactive fish communities in the coastal streams of North-western France. Journal of Animal Ecology 67: $472-484$

Oberdorff, T., Pont, D., Hugueny, B. \& Porcher, J.-P. 2002. Development and validation of a fish-based index for the assessment of 'river health' in France. Freshwater Biology 47: 17201734 . 
Launois, L., Veslot, J., Irz, P., and Argillier, C. (2010) Selecting fish-based metrics responding to human pressures in French natural lakes and reservoirs:towards the development of a fish-based index (FBI) for French lakes, Ecology of Freshwater Fish 2010.2010 John Wiley \& Sons A S. Accepted for publication October 12, 2010 - author-produced version of the final draft post-refeering

The original publication is available at http:__authorservices.wiley.com_bauthor_onlineLibraryTPS.asp_DOI=10.1111_j.1600-

0633.2010.00467.pdf

Pace, M.L. 1991. Concluding remarks. In: Cole, J.J., Lovett, G. \& Findlay, S., eds. Comparative analyses of ecosystems: patterns, mechanisms, and theories. New York: Springer-Verlag, pp. 361-368.

Pella, H., Sauquet, E. \& Chandesris, A. 2006. Construction of a simplified hydrographic network from the carthage databases ${ }^{\circledR}$. Ingénieries (Antony): 3-14.

Pitt, R., Field, R., Lalor, M. \& Brown, M. 1995. Urban Stormwater Toxic Pollutants Assessment, Sources, and Treatability. Water Environment Research 67: 260-275.

Politou, C.Y., Economidis, P.S. \& Sinis, A.I. 1993. Feeding biology of bleak, Alburnus alburnus, in Lake Koronia, northern Greece. Journal of Fish Biology 43: 33-43.

Pont, D., Hugueny, B., Beier, U., Goffaux, D., Noble, R., Rogers, C., Roset, N. \& Schmutz, S. 2006. Assessing river biotic condition at a continental scale: a European approch using functional metrics and fish assemblages. Journal of Applied Ecology 43: 70-80.

Pont, D., Hugueny, B. \& Rogers, C. 2007. Development of a fish-based index for the assessment of river health in Europe: the European Fish Index. Fisheries Management and Ecology 14: 427-440.

R Development Core Team. 2008. R: A language and environment for statistical computing. Vienna, Austria. Available at: http://www.R-project.org: R Foundation for Statistical Computing.

Roset, N., Grenouillet, G., Goffaux, D., Pont, D. \& Kestemont, P. 2007. A review of existing fish assemblage indicators and methodologies. Fisheries Management and Ecology 14: 393405.

Shannon, C.E. \& Weaver, W. 1949. The Mathematical Theory of Communication. Urbana: University of Illinois Press.

Shaw, B., Klessig, L. \& Mechenich, C. 2004. Understanding Lake Data. 20 pp.

Simon, T.P. \& Lyons, J. 1995. Application of the index of biotic integrity to evaluate water resource integrity in freshwater ecosystems. In: Davies, W.S. \& Simon, T.P., eds. Biological assessment and criteria: tools for water resource planning and decision making. Boca Raton, Florida: Lewis Publishers, pp. 245-262.

Simpson, E. 1949. Measurement of diversity. Nature 163: 688.

Thornton, K.W. 1990. Perspectives on reservoir limnology. In: Thornton, K.W., Kimmel, B.L. \& Payne, F.E., eds. Reservoir limnology: ecological perspective. New York: John Wiley \& Sons, Inc., pp. 1-13.

Vitousek, P.M., Aber, J.D., Howarth, R.W., Likens, G.E., Matson, P.A., Schindler, D.W., Schlesinger, W.H. \& Tilman, D. 1997. Human alteration of the global nitrogen cycle: sources and consequences. Ecological Applications 7: 737-750.

Wetzel, R.G. 1990. Reservoir ecosystems: conclusions and speculations. In: Thornton, K.W., Kimmel, B.L. \& Payne, F.E., eds. Reservoir limnology: ecological perspective. New York: John Wiley \& Sons, Inc., pp. 227-238.

Whittier, T.R. 1999. Development of IBI metrics for lakes in Southern New England. In: Simon, T.P., ed. Assessing the sustainability and biological integrity of water resource quality using fish communities. Boca Raton, Florida: CRC Press, pp. 563-584.

Whittier, T.R., Hughes, R.M., Stoddard, J.L., Lomnicky, G.A., Peck, D.V. \& Herlihy, A.T. 2007. A Structured Approach for Developing Indices of Biotic Integrity: Three Examples from Streams and Rivers in the Western USA. Transactions of the American Fisheries Society 136: 718-735.

Winfield, I.J. 2004. Fish in the littoral zone: ecology, threats and management. Limnologica 34: 124-131. 
Launois, L., Veslot, J., Irz, P., and Argillier, C. (2010) Selecting fish-based metrics responding to human pressures in French natural lakes and reservoirs:towards the development of a fish-based index (FBI) for French lakes, Ecology of Freshwater Fish 2010.2010 John Wiley \& Sons A S. Accepted for publication October 12, 2010 - author-produced version of the final draft post-refeering

The original publication is available at http:__authorservices.wiley.com_bauthor_onlineLibraryTPS.asp_DOI=10.1111 j.1600-

0633.2010.00467.pdf

\section{Figure captions}

Figure 1: Location of the 89 study sites in the French hydrographic network. $\diamond$ Natural lakes $\diamond$ Reservoirs 
Launois, L., Veslot, J., Irz, P., and Argillier, C. (2010) Selecting fish-based metrics responding to human pressures in French natural lakes and reservoirs:towards the development of a fish-based index (FBI) for French lakes, Ecology of Freshwater Fish 2010.2010 John Wiley \& Sons A S. Accepted for publication October 12, 2010 - author-produced version of the final draft post-refeering

The original publication is available at http:__authorservices.wiley.com_bauthor_onlineLibraryTPS.asp_DOI=10.1111_j.1600-

0633.2010.00467.pdf

\section{Tables}

Table 1: Environmental parameter mean values, and extreme values of the 89 study sites.

\begin{tabular}{lcccc}
\hline & \multicolumn{2}{c}{ Reservoirs $(\mathrm{n}=59)$} & \multicolumn{2}{c}{ Natural lakes $(\mathrm{n}=30)$} \\
Parameter & Mean & Range & Mean & Range \\
\hline Geologic Index $(\mathrm{GI})(\%$ of the drainage & & & & \\
basin as calcareous) & 0.26 & $0 \sim 1$ & 0.38 & $0 \sim 1$ \\
Residence Time $(\mathrm{RT})($ day) & 137.09 & $0.11 \sim 922.80$ & 692.08 & $5 \sim 5095$ \\
Water level maximal amplitude $(\mathrm{WL})^{\mathrm{a}}$ & 1.53 & $0 \sim 2$ & 0.45 & $0 \sim 2$ \\
Catchment area $\left(\mathrm{A}_{\mathrm{DB}}\right)\left(\mathrm{km}^{2}\right)$ & 662.23 & $8.42 \sim 10533.34$ & 152.80 & $1.25 \sim 1033.34$ \\
Lake area $\left(\mathrm{A}_{\mathrm{L}}\right)(\mathrm{ha})$ & 251.00 & $44 \sim 2272$ & 781.00 & $13 \sim 5768$ \\
Maximum depth $\left(\mathrm{D}_{\max }\right)(\mathrm{m})$ & 23.87 & $2 \sim 100$ & 23.13 & $2 \sim 110$ \\
Shoreline development factor $(\mathrm{SLDF})^{\mathrm{b}}$ & 3.34 & $1.01 \sim 9.20$ & 1.62 & $1.01 \sim 3.80$ \\
$\mathrm{~T}^{\circ} \mathrm{C}$ mean Jan $+\mathrm{T}^{\circ} \mathrm{C}$ mean Jul $(\mathrm{SumT})$ & 23.86 & $15.49 \sim 31.27$ & 20.44 & $13.18 \sim 31.51$ \\
$\mathrm{~T}^{\circ} \mathrm{C}$ mean Jul $-\mathrm{T}^{\circ} \mathrm{C}$ mean Jan $(\mathrm{DiffT})$ & 15.97 & $10.43 \sim 19.42$ & 17.19 & $13.48 \sim 19.91$ \\
Volume development $\left(\mathrm{V}_{\mathrm{d}}\right)^{\mathrm{c}}$ & 1.21 & $0.37 \sim 2.96$ & 1.42 & $0.30 \sim 2.66$ \\
\hline
\end{tabular}

${ }^{\mathrm{b}} 3$ classes: 0 (no variation), $1(\leq 3 \mathrm{~m}), 2(>3 \mathrm{~m})$

${ }^{\mathrm{b}}$ Calculated as: perimeter / $(\sqrt{ } 4 \pi \times$ surface $)$.

'Calculated as: $3 \times$ Lake volume $/$ (Maximum depth $\times$ Lake area). 
Launois, L., Veslot, J., Irz, P., and Argillier, C. (2010) Selecting fish-based metrics responding to human pressures in French natural lakes and reservoirs:towards the development of a fish-based index (FBI) for French lakes, Ecology of Freshwater Fish 2010. 2010 John Wiley \& Sons A/S. Accepted for publication October 12, 2010 - author-produced version of the final draft post-refeering

The original publication is available at http:__authorservices.wiley.com_bauthor_onlineLibraryTPS.asp_DOI=10.1111_j.1600-0633.2010.00467.pdf

Table 2: Description of the anthropogenic variables included in the analysis; and principal component analysis (PCA) carried out on the watershed pressure variables. Table entries are the variable correlations with the first principal component on each of the two PCAs, one carried out on agricultural variables only (PA) and another carried out on urban variables only (PU). Those loading most heavily on each PC are in bold.

\begin{tabular}{|c|c|c|c|c|c|c|c|}
\hline \multirow[b]{2}{*}{ Variable } & \multirow[b]{2}{*}{ Inertia } & \multicolumn{2}{|c|}{ All lakes $(n=146)$} & \multicolumn{2}{|c|}{ Reservoirs $(n=59)$} & \multicolumn{2}{|c|}{ Naturals $(n=30)$} \\
\hline & & $\begin{array}{c}\text { PA } \\
63 \%\end{array}$ & $\begin{array}{c}\text { PU } \\
72 \%\end{array}$ & Mean & Range & Mean & Range \\
\hline$\%$ catchment agricultural & & 0.84 & - & 51.41 & $0 \sim 93.80$ & 24.30 & $0 \sim 87.50$ \\
\hline Agriculture land cover area $\left(\mathrm{km}^{2}\right)$ & & 0.65 & - & 427.06 & $0 \sim 8783.40$ & 54.35 & $0 \sim 790.60$ \\
\hline Nitrogen balance $(\mathrm{t})$ & & 0.79 & - & 122.19 & $-598.20 \sim 877.10$ & -40.44 & $-346.80 \sim 432.30$ \\
\hline Phosphorus balance $(\mathrm{t}){ }^{*}$ erodibility coefficient & & 0.88 & - & 421.71 & $-156.60 \sim 2523.10$ & -12.95 & $-389.10 \sim 849.20$ \\
\hline$\%$ catchment urban & & - & 0.90 & 3.95 & $0 \sim 55$ & 3.40 & $0 \sim 15.30$ \\
\hline Population density in catchment (people $/ \mathrm{km}^{2}$ ) & & - & 0.86 & 65.33 & $4.10 \sim 1006.50$ & 40.02 & $3.70 \sim 260.50$ \\
\hline Transportation network density & & - & 0.78 & 2.17 & $0 \sim 10.30$ & 2.09 & $0 \sim 11.30$ \\
\hline
\end{tabular}


Launois, L., Veslot, J., Irz, P., and Argillier, C. (2010) Selecting fish-based metrics responding to human pressures in French natural lakes and reservoirs:towards the development of a fish-based index (FBI) for French lakes, Ecology of Freshwater Fish 2010.2010 John Wiley \& Sons A S. Accepted for publication October 12, 2010 - author-produced version of the final draft post-refeering

The original publication is available at http:__authorservices.wiley.com_bauthor_onlineLibraryTPS.asp_DOI=10.1111_j.1600-

0633.2010.00467.pdf

Table 3: Occurrence rates of the 42 fish species in natural lakes and reservoirs. Rates over $\mathbf{7 5 \%}$ are in bold.

\begin{tabular}{|c|c|c|c|c|c|}
\hline Common name & Species & $\begin{array}{c}\text { Frequency } \\
\text { Reservoirs } \\
(\%)\end{array}$ & $\begin{array}{c}\text { Frequency } \\
\text { Naturals (\%) }\end{array}$ & $\begin{array}{c}\text { Average Relative } \\
\text { Abundance } \\
\text { Reservoirs (\%) }\end{array}$ & $\begin{array}{c}\text { Average Relative } \\
\text { Abundance } \\
\text { Naturals (\%) }\end{array}$ \\
\hline Bream & Abramis brama & 76.67 & 51.61 & 9.25 & 4.87 \\
\hline Sterlet & Acipenser ruthenus & 1.67 & 0.00 & 0.00 & 0.00 \\
\hline Spirlin & $\begin{array}{l}\text { Alburnoides } \\
\text { bipunctatus }\end{array}$ & 0.00 & 3.23 & 0.00 & 0.02 \\
\hline Bleak & Alburnus alburnus & 53.33 & 29.03 & 2.05 & 2.25 \\
\hline Brown Bullhead & Ameiurus melas & 28.33 & 29.03 & 7.13 & 1.18 \\
\hline European eel & Anguilla anguilla & 1.67 & 3.23 & 0.01 & 0.00 \\
\hline Stone Loach & Barbatula barbatula & 5.00 & 6.45 & 0.22 & 0.10 \\
\hline Barbel & Barbus barbus & 6.67 & 0.00 & 0.04 & 0.00 \\
\hline White Bream & Blicca bjoerkna & 66.67 & 22.58 & 8.05 & 3.46 \\
\hline Goldfish & $\begin{array}{l}\text { Carassius auratus } \\
\text { auratus }\end{array}$ & 8.33 & 0.00 & 0.01 & 0.00 \\
\hline Crucian Carp & Carassius carassius & 11.67 & 9.68 & 0.03 & 0.10 \\
\hline Common Whitefish & Coregonus lavaretus & 3.33 & 32.26 & 0.03 & 1.61 \\
\hline Bullhead & Cottus gobio & 1.67 & 6.45 & 0.02 & 0.04 \\
\hline Common Carp & Cyprinus carpio & 38.33 & 19.35 & 0.23 & 0.03 \\
\hline Northern Pike & Esox lucius & 58.33 & 67.74 & 0.35 & 0.27 \\
\hline Mosquitofish & Gambusia affinis & 1.67 & 0.00 & 0.01 & 0.00 \\
\hline Gudgeon & Gobio gobio & 15.00 & 32.26 & 2.07 & 1.07 \\
\hline Ruffe & $\begin{array}{l}\text { Gymnocephalus } \\
\text { cernuus }\end{array}$ & 63.33 & 38.71 & 6.08 & 3.17 \\
\hline Silver carp & $\begin{array}{l}\text { Hypophthalmichthys } \\
\text { molitrix }\end{array}$ & 1.67 & 0.00 & 0.01 & 0.00 \\
\hline Pumpkinseed & Lepomis gibbosus & 30.00 & 32.26 & 0.19 & 0.23 \\
\hline Belica & Leucaspius delineatus & 3.33 & 3.23 & 0.00 & 0.25 \\
\hline Ide & Leuciscus idus & 1.67 & 0.00 & 0.00 & 0.00 \\
\hline Common Dace & Leuciscus leuciscus & 3.33 & 9.68 & 0.03 & 0.03 \\
\hline Golden grey mullet & Liza aurata & 1.67 & 0.00 & 0.00 & 0.00 \\
\hline Thinlip Mullet & Liza ramada & 1.67 & 0.00 & 0.12 & 0.00 \\
\hline Burbot & Lota lota & 0.00 & 3.23 & 0.00 & 0.00 \\
\hline Rainbow Trout & Oncorhynchus mykiss & 10.00 & 9.68 & 0.83 & 0.42 \\
\hline European Perch & Perca fluviatilis & 93.33 & 93.55 & 21.95 & 28.72 \\
\hline Eurasian Minnow & Phoxinus phoxinus & 5.00 & 3.23 & 0.41 & 1.81 \\
\hline Bitterling & Rhodeus amarus & 3.33 & 0.00 & 0.03 & 0.00 \\
\hline Roach & Rutilus rutilus & 91.67 & 96.77 & 31.31 & 38.85 \\
\hline Freshwater Blenny & Salaria fluviatilis & 0.00 & 3.23 & 0.00 & 0.01 \\
\hline Brown Trout & Salmo trutta fario & 15.00 & 16.13 & 1.13 & 0.65 \\
\hline Charr & Salvelinus alpinus & 0.00 & 9.68 & 0.00 & 0.78 \\
\hline Lake Trout & Salvelinus namaycush & 0.00 & 3.23 & 0.00 & 0.04 \\
\hline Pike Perch & Sander lucioperca & 78.33 & 41.94 & 4.41 & 1.83 \\
\hline Rudd & $\begin{array}{l}\text { Scardinius } \\
\text { erythrophthalmus }\end{array}$ & 81.67 & 70.97 & 3.39 & 5.88 \\
\hline Wels Catfish & Silurus glanis & 21.67 & 9.68 & 0.05 & 0.01 \\
\hline European Chub & Squalius cephalus & 21.67 & 38.71 & 0.44 & 1.06 \\
\hline Western vairone & Telestes souffia & 0.00 & 3.23 & 0.00 & 0.79 \\
\hline Grayling & Thymallus thymallus & 1.67 & 0.00 & 0.02 & 0.00 \\
\hline Tench & Tinca tinca & 25.00 & 35.48 & 0.09 & 0.45 \\
\hline
\end{tabular}


Launois, L., Veslot, J., Irz, P., and Argillier, C. (2010) Selecting fish-based metrics responding to human pressures in French natural lakes and reservoirs:towards the development of a fish-based index (FBI) for French lakes, Ecology of Freshwater Fish 2010. 2010 John Wiley \& Sons A S. Accepted for publication October 12, 2010 - author-produced version of the final draft post-refeering

The original publication is available at http:__authorservices.wiley.com_bauthor_onlineLibraryTPS.asp_DOI=10.1111_j.1600-0633.2010.00467.pdf

\section{Table 4: Proposed guild classification for French lake fishes}

\section{Guilds}

Tolerance guild

(Karr et al. 1986)

Reproduction guild

(Balon 1975; Dycus \& Meinert

1994)

Trophic guild

(Bruslé \& Quignard 2001; Dycus

\& Meinert 1994; Goldstein \&

Simon 1999; Pont et al. 2006)

Overall Tolerants

Overall Intolerants

Lithophilic

Strict Lithophilic

Strict Phytophilic

Omnivores

Invertivores

Planktivores

Herbivores

Piscivores

\section{Definitions}

Species sensitive to any common impact related to altered flow regime, nutrient regime, habitat structure and water chemistry. Loss of intolerant species is a response to degradation, whereas the number of tolerant species will tend to increase with disturbance.

Can reproduce on unsilted mineral substrates whose larvae are photophobic.

Need mineral substrates to reproduce.

Need plant substrates to reproduce and whose larvae are not photophobic.

Feed on both animal and vegetal items (more than 25\% plant material and more than $25 \%$ animal material).

Feed at least partially on invertebrates/insects (more than $75 \%$ macro-invertebrates in the diet).

Feed mainly on zooplankton and/or phytoplankton (more than $75 \%$ of plankton in the diet).

Feed on plant items (more than $75 \%$ of plant material in the diet).

Feed on fish at least partially when adults (more than $75 \%$ fish in the diet). 
Launois, L., Veslot, J., Irz, P., and Argillier, C. (2010) Selecting fish-based metrics responding to human pressures in French natural lakes and reservoirs:towards the development of a fish-based index (FBI) for French lakes, Ecology of Freshwater Fish 2010. 2010 John Wiley \& Sons A S. Accepted for publication October 12, 2010 - author-produced version of the final draft post-refeering

The original publication is available at http:__authorservices.wiley.com_bauthor_onlineLibraryTPS.asp_DOI=10.1111_j.1600-0633.2010.00467.pdf

Table 5: Mean values (standard deviation) of the fish-based metrics and $p$-values of Student $t$-test (with Welch correction if needed) obtained from the functional traits between natural lakes and reservoirs; $P \leq 0.05 *, P \leq 0.01 * *, P \leq 0.001 * * *$.

\begin{tabular}{|c|c|c|c|c|c|c|c|c|c|c|}
\hline \multirow[b]{2}{*}{ Functional traits } & \multicolumn{5}{|c|}{ Reservoirs $(n=59)$} & \multicolumn{5}{|c|}{ Naturals $(n=30)$} \\
\hline & CPUE & $\begin{array}{l}\text { Proportion } \\
\text { in number of } \\
\text { individuals }\end{array}$ & BPUE & $\begin{array}{l}\text { Proportion in } \\
\text { biomass of } \\
\text { individuals }\end{array}$ & $\begin{array}{l}\text { Species } \\
\text { Richness }\end{array}$ & CPUE & $\begin{array}{l}\text { Proportion } \\
\text { in number of } \\
\text { individuals }\end{array}$ & BPUE & $\begin{array}{l}\text { Proportion in } \\
\text { biomass of } \\
\text { individuals }\end{array}$ & $\begin{array}{l}\text { Species } \\
\text { Richness }\end{array}$ \\
\hline $\begin{array}{l}\text { Overall Species } \\
\text { Richness }\end{array}$ & - & 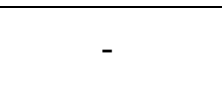 & - & 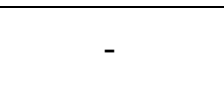 & $9.50(2.60)$ & - & 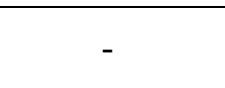 & - & 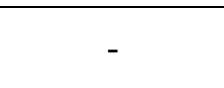 & $8.40(2.50)$ \\
\hline Shannon index & - & - & - & - & $1.29(0.32)^{*}$ & - & - & - & - & $1.15(0.21)^{*}$ \\
\hline Simpson index & - & - & - & - & $0.63(0.13)$ & - & - & - & - & $0.58(0.10)$ \\
\hline Evenness index & - & - & - & - & $0.59(0.13)$ & - & - & - & - & $0.56(0.11)$ \\
\hline Natives & $0.08(0.09)$ & $0.66(0.32)$ & $3.30(2.70)$ & $0.62(0.30)$ & $5.70(2.40)$ & $0.06(0.10)$ & $0.78(0.35)$ & $2.40(2.20)$ & $0.74(0.29)$ & $5.70(2.60)$ \\
\hline Intolerants & $0.00(0.00)$ & $0.01(0.07)$ & $0.04(0.20)^{*}$ & $0.02(0.09)^{* *}$ & $0.30(0.60)^{*}$ & $0.00(0.01)$ & $0.04(0.08)$ & $0.2(0.30)^{*}$ & $0.09(0.15)^{* *}$ & $0.80(1.10)^{*}$ \\
\hline Tolerants & $0.09(0.09)$ & $0.80(0.23)$ & $\begin{array}{c}3.90 \\
(2.70)^{\star *}\end{array}$ & $0.74(0.20)^{*}$ & $\begin{array}{c}5.40 \\
(1.90)^{\star *}\end{array}$ & $0.08(0.11)$ & $0.80(0.21)$ & $\begin{array}{c}2.40 \\
(2.10)^{\star *}\end{array}$ & $0.64(0.20)^{*}$ & $\begin{array}{c}4.20 \\
(1.70)^{\star *}\end{array}$ \\
\hline Lithophilic & $0.09(0.09)$ & $0.88(0.19)$ & $\begin{array}{c}4.20 \\
(2.60)^{\star \star}\end{array}$ & $0.83(0.17)$ & $6.60(2.00)$ & $0.08(0.12)$ & $0.91(0.14)$ & $\begin{array}{c}2.60 \\
(2.00)^{\star \star}\end{array}$ & $0.79(0.23)$ & $6.20(2.20)$ \\
\hline Strict lithophilic & $0.00(0.02)$ & $0.10(0.19)$ & $0.50(0.80)$ & $0.11(0.19)$ & $1.10(1.00)$ & $0.00(0.01)$ & $0.08(0.17)$ & $0.30(0.40)$ & $0.13(0.20)$ & $1.70(1.50)$ \\
\hline Strict phytophilic & $0.02(0.04)$ & $0.12(0.19)$ & $0.90(1.10)$ & $0.16(0.16)$ & $2.80(1.30)^{*}$ & $0.01(0.02)$ & $0.08(0.14)$ & $0.80(1.60)$ & $0.21(0.23)$ & $2.20(1.20)^{*}$ \\
\hline Omnivores & $0.05(0.05)$ & $0.47(0.22)$ & $2.90(2.10)^{*}$ & $0.55(0.19)$ & $3.90(1.50)^{*}$ & $0.06(0.10)$ & $0.54(0.26)$ & $2.00(1.70)^{*}$ & $0.51(0.21)$ & $3.20(1.20)^{*}$ \\
\hline Invertivores & $0.10(0.09)$ & $\begin{array}{c}0.95 \\
(0.05)^{\star *}\end{array}$ & $4.40(2.70)^{*}$ & $0.86(0.10)$ & $8.10(2.30)$ & $0.09(0.12)$ & $\begin{array}{c}0.98 \\
(0.03)^{\star *}\end{array}$ & $3.10(2.30)^{*}$ & $0.90(0.11)$ & $7.30(2.20)$ \\
\hline Planktivores & $0.06(0.07)$ & $0.55(0.26)$ & $3.40(2.60)^{*}$ & $0.62(0.20)$ & $5.00(1.90)^{*}$ & $0.06(0.11)$ & $0.57(0.26)$ & $2.20(1.90)^{*}$ & $0.58(0.20)$ & $4.20(1.60)^{*}$ \\
\hline Herbivores & $0.03(0.04)$ & $0.34(0.22)$ & $1.30(0.90)$ & $0.28(0.17)$ & $1.60(0.80)$ & $0.04(0.07)$ & $0.41(0.21)$ & $0.90(0.80)$ & $0.27(0.13)$ & $1.80(0.90)$ \\
\hline Piscivores & $0.04(0.06)$ & $0.36(0.25)$ & $1.60(1.20)$ & $0.35(0.19)$ & $3.60(1.20)$ & $0.03(0.04)$ & $0.36(0.24)$ & $1.30(1.00)$ & $0.44(0.21)$ & $3.60(1.20)$ \\
\hline
\end{tabular}


Launois, L., Veslot, J., Irz, P., and Argillier, C. (2010) Selecting fish-based metrics responding to human pressures in French natural lakes and reservoirs:towards the development of a fish-based index (FBI) for French lakes, Ecology of Freshwater Fish 2010. 2010 John Wiley \& Sons A S. Accepted for publication October 12, 2010 - author-produced version of the final draft post-refeering

The original publication is available at http:__authorservices.wiley.com_bauthor_onlineLibraryTPS.asp_DOI=10.1111_j.1600-0633.2010.00467.pdf

Table 6: Regression of fish metrics versus the environmental and anthropogenic variables. Table entries are the regression coefficient model, $R$ square adjusted, coefficient significance level, and variance partitioning; var env is the percentage of the total variation attributable to pure environmental effects, var PA to pure agricultural pressure effects, var $P U$ to pure urban pressure effects, and unexpl variation unexplained by the model. For abbreviations see section "Candidate metrics".

\begin{tabular}{|c|c|c|c|c|c|c|c|c|}
\hline & & PA & PU & $\mathrm{R}^{2}$-adjusted & var env & var PA & var PU & unexpl \\
\hline Reservoirs & BPUE & $0.09^{*}$ & - & 0.56 & 0.37 & $0.03^{*}$ & $<0.00$ & 0.40 \\
\hline \multirow[t]{7}{*}{$n=59$} & Sp_OTol & $0.20^{* *}$ & - & 0.39 & 0.18 & $0.07^{*}$ & 0.00 & 0.59 \\
\hline & B_OTol & $0.20^{* * *}$ & - & 0.68 & 0.38 & $0.06^{* *}$ & 0.01 & 0.33 \\
\hline & Sp_Omni & $0.20^{* * *}$ & - & 0.25 & 0.01 & $0.10^{*}$ & 0.02 & 0.79 \\
\hline & Sp_Plankt & $0.20^{* * *}$ & - & 0.34 & 0.10 & $0.10^{*}$ & 0.01 & 0.70 \\
\hline & $\%$ Sp_Plankt & $0.06^{* * *}$ & - & 0.21 & $<0.00$ & $0.12^{\star *}$ & $<0.00$ & 0.85 \\
\hline & B_Herb & $0.20^{* * *}$ & - & 0.33 & 0.14 & $0.13^{* *}$ & 0.02 & 0.71 \\
\hline & $\%$ Sp_Pisc & $-0.08^{* * *}$ & - & 0.28 & 0.06 & $0.17^{\star *}$ & $<0.00$ & 0.73 \\
\hline Natural lakes & \%B_OTol & - & $0.20^{* * *}$ & 0.43 & 0.27 & $<0.00$ & $0.30^{* *}$ & 0.51 \\
\hline \multirow[t]{2}{*}{$n=30$} & Nb_StPhyto & $0.03^{* * *}$ & - & 0.66 & 0.23 & $0.20^{* *}$ & 0.01 & 0.39 \\
\hline & \%B_Plankt & $0.20^{*}$ & - & 0.42 & 0.28 & $0.17^{*}$ & $<0.00$ & 0.65 \\
\hline
\end{tabular}

*significant at 0.05 level; ** significant at 0.01 level; ${ }^{* * *}$ significant at 0.001 level 
Launois, L., Veslot, J., Irz, P., and Argillier, C. (2010) Selecting fish-based metrics responding to human pressures in French natural lakes and reservoirs:towards the development of a fish-based index (FBI) for French lakes, Ecology of Freshwater Fish 2010. 2010 John Wiley \& Sons A/S. Accepted for publication October 12, 2010 - author-produced version of the final draft post-refeering

The original publication is available at http:__authorservices.wiley.com_bauthor_onlineLibraryTPS.asp_DOI=10.1111_j.1600-0633.2010.00467.pdf

Appendix 1: Assignment of the 42 fish species into reproductive, trophic, and tolerance guilds used to derive assemblage traits.

\begin{tabular}{|c|c|c|c|c|c|c|c|c|c|c|}
\hline Species & $\begin{array}{c}\text { Overall } \\
\text { Intolerant } \\
\text { species }\end{array}$ & $\begin{array}{c}\text { Overall } \\
\text { Tolerant } \\
\text { species } \\
\end{array}$ & Lithophilic & $\begin{array}{c}\text { Strict } \\
\text { Lithophilic }\end{array}$ & $\begin{array}{c}\text { Strict } \\
\text { Phytophilic }\end{array}$ & $\begin{array}{l}\text { Omnivores } \\
\text { Generalist }\end{array}$ & Invertivores & Planktivores & Herbivores & Piscivores \\
\hline Abramis brama & 0 & 1 & 1 & 0 & 0 & 1 & 1 & 1 & 0 & 0 \\
\hline Acipenser ruthenus & 0 & 0 & 1 & 1 & 0 & 0 & 1 & 0 & 0 & 0 \\
\hline Alburnoides bipunctatus & 1 & 0 & 1 & 1 & 0 & 0 & 1 & 1 & 0 & 0 \\
\hline Alburnus alburnus & 0 & 1 & 1 & 0 & 0 & 1 & 1 & 1 & 0 & 0 \\
\hline Ameiurus melas & 0 & 1 & 1 & 1 & 0 & 0 & 1 & 0 & 0 & 1 \\
\hline Anguilla anguilla & 0 & 1 & 0 & 0 & 0 & 0 & 1 & 0 & 0 & 1 \\
\hline Barbatula barbatula & 0 & 0 & 1 & 0 & 0 & 0 & 1 & 0 & 0 & 0 \\
\hline Barbus barbus & 0 & 0 & 1 & 1 & 0 & 0 & 1 & 0 & 0 & 0 \\
\hline Blicca bjoerkna & 0 & 1 & 0 & 0 & 1 & 0 & 1 & 1 & 0 & 0 \\
\hline Carassius auratus auratus & 0 & 1 & 0 & 0 & 1 & 1 & 1 & 1 & 1 & 0 \\
\hline Carassius carassius & 0 & 1 & 0 & 0 & 1 & 1 & 1 & 1 & 1 & 0 \\
\hline Coregonus lavaretus & 1 & 0 & 1 & 1 & 0 & 0 & 1 & 1 & 0 & 0 \\
\hline Cottus gobio & 1 & 0 & 1 & 1 & 0 & 0 & 1 & 0 & 0 & 0 \\
\hline Cyprinus carpio & 0 & 1 & 1 & 0 & 0 & 1 & 1 & 1 & 0 & 0 \\
\hline Esox lucius & 0 & 0 & 0 & 0 & 1 & 0 & 0 & 0 & 0 & 1 \\
\hline Gambusia affinis & 0 & 1 & 0 & 0 & 0 & 0 & 1 & 1 & 0 & 0 \\
\hline Gobio gobio & 0 & 0 & 1 & 0 & 0 & 0 & 1 & 0 & 1 & 0 \\
\hline Gymnocephalus cernuus & 0 & 0 & 1 & 0 & 0 & 0 & 1 & 0 & 0 & 0 \\
\hline Hypophthalmichthys molitrix & 0 & 1 & 0 & 0 & 0 & 0 & 0 & 1 & 1 & 0 \\
\hline Lepomis gibbosus & 0 & 1 & 1 & 1 & 0 & 0 & 1 & 1 & 0 & 0 \\
\hline Leucaspius delineatus & 1 & 0 & 0 & 0 & 1 & 0 & 1 & 1 & 0 & 0 \\
\hline Leuciscus idus & 1 & 0 & 1 & 0 & 0 & 1 & 1 & 1 & 1 & 1 \\
\hline Leuciscus leuciscus & 0 & 0 & 1 & 1 & 0 & 1 & 1 & 1 & 0 & 0 \\
\hline Liza aurata & 0 & 0 & 0 & 0 & 0 & 1 & 0 & 1 & 1 & 0 \\
\hline Liza ramada & 0 & 1 & 1 & 1 & 0 & 0 & 1 & 0 & 1 & 0 \\
\hline Lota lota & 0 & 0 & 1 & 1 & 0 & 0 & 1 & 0 & 0 & 1 \\
\hline Oncorhynchus mykiss & 0 & 0 & 1 & 1 & 0 & 0 & 1 & 0 & 0 & 1 \\
\hline Perca fluviatilis & 0 & 1 & 1 & 0 & 0 & 0 & 1 & 0 & 0 & 1 \\
\hline Phoxinus phoxinus & 0 & 0 & 1 & 1 & 0 & 0 & 1 & 0 & 0 & 0 \\
\hline Rhodeus amarus & 1 & 0 & 0 & 0 & 0 & 0 & 1 & 0 & 1 & 0 \\
\hline
\end{tabular}


Launois, L., Veslot, J., Irz, P., and Argillier, C. (2010) Selecting fish-based metrics responding to human pressures in French natural lakes and reservoirs:towards the development of a fish-based index (FBI) for French lakes, Ecology of Freshwater Fish 2010. 2010 John Wiley \& Sons A/S. Accepted for publication October 12, 2010 - author-produced version of the final draft post-refeering

The original publication is available at http:__authorservices.wiley.com_bauthor_onlineLibraryTPS.asp_DOI=10.1111_j.1600-0633.2010.00467.pdf

Rutilus rutilus

Salaria fluviatilis

Salmo trutta fario

Salvelinus alpinus

Salvelinus namaycush

Sander lucioperca

Scardinius

erythrophthalmus

Silurus glanis

Squalius cephalus

Telestes souffia

Thymallus thymallus

Tinca tinca

\begin{tabular}{|c|c|c|c|c|c|c|c|c|c|}
\hline 0 & 1 & 1 & 0 & 0 & 1 & 1 & 1 & 1 & 0 \\
\hline 0 & 0 & 1 & 1 & 0 & 0 & 1 & 0 & 0 & 0 \\
\hline 1 & 0 & 1 & 1 & 0 & 0 & 1 & 0 & 0 & 1 \\
\hline 1 & 0 & 1 & 1 & 0 & 0 & 1 & 0 & 0 & 1 \\
\hline 1 & 0 & 1 & 1 & 0 & 0 & 1 & 0 & 0 & 1 \\
\hline 0 & 0 & 1 & 0 & 0 & 0 & 0 & 0 & 0 & 1 \\
\hline 0 & 0 & 0 & 0 & 1 & 1 & 1 & 1 & 0 & 0 \\
\hline 0 & 0 & 0 & 0 & 1 & 0 & 1 & 0 & 0 & 1 \\
\hline 0 & 0 & 1 & 0 & 0 & 1 & 1 & 1 & 1 & 1 \\
\hline 1 & 0 & 1 & 1 & 0 & 0 & 1 & 0 & 0 & 0 \\
\hline 1 & 0 & 1 & 1 & 0 & 0 & 1 & 0 & 0 & 0 \\
\hline 0 & 1 & 0 & 0 & 1 & 0 & 1 & 0 & 0 & 1 \\
\hline
\end{tabular}

